Agro-Science Journal of Tropical Agriculture, Food, Environment and Extension Volume 10 Number 1 January 2011 pp. $41-60$

ISSN 1119-7455

\title{
CLIMATE CHANGE AND LIVESTOCK PRODUCTION IN NIGERIA: ISSUES AND CONCERNS
}

\author{
Nwosu C. C and Ogbu. C.C. \\ Department of Animal Science, University of Nigeria, Nsukka, Nigeria.
}

\begin{abstract}
:
The article reviewed the major issues concerning climate change and livestock production in Nigeria. The mechanism of the greenhouse effect (GHE) of the earth's atmosphere as well as the relative importance of greenhouse gases (GHGs) in terms of greenhouse effect (GHE) and global warming potential (GWP) are presented. The probable changes in global climate as a result of atmospheric enrichment with greenhouse gases from results of simulated changes in atmospheric greenhouse gases are also presented. Emission scenarios and climate change models, atmospheric enrichment with GHGs were shown to have a net negative impact on global climate leading to global warming, more variable and unpredictable climatic and weather patterns (including tendencies for extreme events), net decrease in yield of grain, forage and pasture crops for livestock as well as changes in the epidemiology and dynamics of livestock diseases, pests and vectors. These stressors meant greater challenges on livestock production in terms of well being, reproduction and performance. A number of adaptation schemes which include environmental modification, selective breeding and modifications in the nutritional environment of animals were suggested. The integration of these adaptive measures in livestock production systems in Nigeria will minimize and/or forestall the negative impacts of climatic change and climate variability on livestock production in Nigeria.
\end{abstract}

\section{INTRODUCTION}

Livestock production systems be they intensive, semi-intensive or extensive are an assemblage of a myriad of interacting factors which result from complex actions that implicate the transformation of organic and inorganic substances into organic animal materials and products (Boyazoglu and Nardone, 2003). Each of the numerous processes involved is influenced by a number of natural and human factors (Nardone, 2000; Hatfield et al., 2008). The human factors include culture and tradition, population and social structure, economic and technological development, as well as human needs for food security. The animal factors include the species and within these, the breeds better adapted to exploit specific ecological niches. Major components of the natural factors are the climate with its various characteristic variables: temperature, rainfall, humidity, solar radiation and airflow which determine not only the quality and quantity of cultivated and spontaneous animal feed resources (grain, forage and pasture crops) but also the quality of life and performance of each animal species (Boyazoglu and Nardone, 2003; Baylis and Githeko, 2006). The forests of the humid and sub-humid ecosystems, the shrub and woody grasslands of the arid and sahel, as well as the grass pastures of the cold and rainy mountainous areas are all products of climate and soil characteristics. Rainfall in association with temperature determine the classification of tropical ecosystems into desertic, subarid, arid, semi-arid, sub-humid and humid ecosystems (Sankaran et al., 2005). Water availability for human use and for livestock and crop farming depends on the frequency and intensity of rainfall (Polley et al., 2000). Human actions result in the production of elements that instigate climate change and thus influence natural systems including global and local climates and these shape and reshape his environment and that of his animals (Boyazoglu and Nardone, 2003). The unprecedented rise in anthropogenic carbon dioxide $\left(\mathrm{CO}_{2}\right)$, methane $\left(\mathrm{CH}_{4}\right)$, nitrous oxide $\left(\mathrm{N}_{2} \mathrm{O}\right)$, ozone $\left(\mathrm{O}_{3}\right)$, halocarbons (e.g. carbon fluoro chloride), etc are 
fingered as mostly responsible for negative shifts in the earth climatic systems (Morghan, 2005; IPCC, 2007; Hegeri et al., 2007; Hatfield et al., 2008). The specific behavioural and performance attributes of each animal species or breed is therefore, the result of the complex interactions with its environment, nature and nurture (Marai et al., 1999; Boyazoglu, 2000; Sevi et al., 2002; Marai and Rashwan, 2004). Climate, therefore, has strong influence on livestock production. According to the values of the parameters which define them, they discriminate by species, breed and animal type by acting directly depending on the animal's comfort zone or indirectly through its effects on fodder production and on the breeding (reproduction) and management systems (Boyazoglu, 1998; 2000; Valtorta, 2002; Frank et al., 2004). The poor performance of tropical breeds is an adaptation to the harsh environmental conditions of the tropics: scarce feed resources, poor forage quality, challenge of pests and diseases, hot, humid and dry conditions, variable rainfall pattern, poor soil quality and land degradation (Da Silva, 2000a; Hatfield, 2009; IFAD, 2009). Climate also influences the spread of animal diseases and pests as well as their vectors (Da Silva, 2000a; Valtorta, 2002; Thomson et al., 2004; Baylis and Githeko, 2006). The combination of rainfall and seasonal temperature averages in the various sub climates of the world, control the length of the plant growth period. Natural plant growth and crop production, therefore, coincides mostly with the periods of sufficient rainfall and moderate temperatures in all ecosystems. The resultant important seasonality of production of natural vegetation (quantity and quality) and cultivated crops influence livestock production in terms of well being and performance. Specific environmental conditions induce specific plant associations. This creates particular ecosystems that provide the forage resources available for grazing.

Nigeria's climate structure mirrors the African and global climate system in terms of its complex weather pattern and subdivision into sub-climatic zones: humid rainforest, savanna, derived savanna and arid/sahelian zones characterized by different rainfall and temperature regimes. Climate change with its attendant shifts in natural climatic systems is therefore, of considerable economic importance to agricultural systems (crop and animal farming) in Nigeria. Drought, elevated temperatures, high humidity, variable and unpredictable rainfall pattern and other adverse weather conditions including extreme events (heat waves, hurricanes, flood, erosion, rain and sand storms, etc) are important limiting factors to livestock production in Nigeria and climate change will exacerbate their negative effects (BNRCC, 2008). This is in addition to the impacts of shifts in the epidemiology and dynamics of animal diseases, pests and vectors (Thomson et al., 2004; Baylis and Githeko, 2006).

The present review highlights the myriad of probable climate change impacts on livestock production in Nigeria. This is aimed at sensitizing policy makers at all levels and stakeholders in the livestock sub sector to the need to integrate climate change adaptation and mitigation measures into livestock production in Nigeria.

The earth's atmosphere, greenhouse gases, elements and drivers of climate change

The earth is made up of the atmosphere - a layer of mixture of gases, water vapour and dust - dynamic in composition and in dynamic equilibrium; the hydrosphere (water bodies) and the lithosphere (land) (Buchdahl, 1999; 2002). The parts of the earth that hold life forms are collectively called the biosphere (thin layer of atmosphere, hydrosphere and lithosphere). The global biosphere is characterized by cycles: energy cycle and chemical cycle and by means of the atmosphere (the greatest, fastest and most reliable natural transport system) substances, energy and chemicals circulate through the biosphere- atmosphere, hydrosphere and lithosphere.

As shown in figure 1 sample of air (atmosphere) will normally contain about $78 \%$ nitrogen $\left(\mathrm{N}_{2}\right), 21 \%$ oxygen $\left(\mathrm{O}_{2}\right)$ and about $1 \%$ of a collection of gases (Carbon dioxide $\left(\mathrm{CO}_{2}\right)$, Ozone $\left(\mathrm{O}_{3}\right)$, Methane $\left(\mathrm{CH}_{4}\right)$, Nitrous oxide $\left(\mathrm{N}_{2} \mathrm{O}\right)$, Argon $(\mathrm{Ar})$, Hydrogen $\left(\mathrm{H}_{2}\right)$, etc) called trace gases on account of their low volume compared to the main constituents of air (Manicore, 2007). 


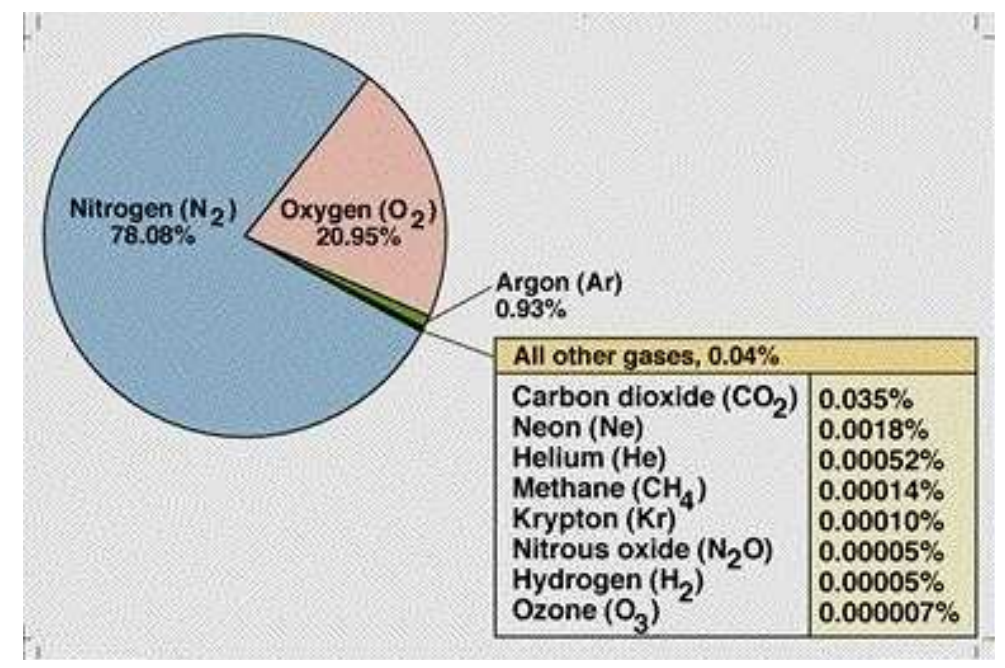

Figure 1: Percentage composition of atmospheric gases; Source: Buchdahl (2002)

Nitrogen in air is not used directly by living organisms but it is very essential for life on earth being a major component of both plant and animal proteins. Oxygen is required for respiration by both plants and animals and is used directly from air. Carbon dioxide is used by plants for photosynthesis. These substances move through the layers of the earth existing in different forms, and are used by different organisms at different times. The trace gases especially $\mathrm{CO}_{2}, \mathrm{CH}_{4}, \mathrm{~N}_{2} \mathrm{O}$, $\left.\mathrm{O}_{3}, \quad \mathrm{H}_{2} \mathrm{O}_{(} \mathrm{g}\right)$ and the halocarbons are called 'greenhouse gases' (GHGs) based on the idea that like the glass walls of a greenhouse, they trap (hold) heat energy and thus prevent heat energy radiated from the earth from escaping into space (Buchdahl, 1999). The gases hence, act as effective global insulators. They are responsible for the green house effect (GHE) of the earth's atmosphere. In addition, they prevent the harmful radiations from the sun (ultraviolet, infrared and far-infrared radiations) from penetrating to the earth, but generally allow the visible light from the sun to pass through to the earth (Buchdahl, 2002; Manicore, 2007). By means of this mechanism, the atmosphere is responsible for the suitable temperature range $\left(0^{\circ} \mathrm{C}-100^{\circ} \mathrm{C}\right.$, average $\left.15^{\circ} \mathrm{C}\right)$ available on earth which is suitable for our active biosphere. The space is freezing cold and will drain the earth of all heat energy without the presence of the GHGs and without the GHE of the earth's atmosphere, the earth will be too cold, mean $-18^{\circ} \mathrm{C}$ (Buchdahl, 1999; 2002). To maintain the required concentration of the GHGs and so the integrity of the atmospheric greenhouse structure, the rate of natural production and uptake of GHGs balance. The natural atmospheric composition of GHGs is, therefore, beneficial. The current negative attributes to the GHGs emanated from an overload of the atmosphere by additional volumes of GHGs from uncontrolled human activities associated with agriculture, fossil fuel combustion, deforestation, changes in solar radiation and land use as well as soil degradation (EC, 2006; IPCC, 2007). The consequent alteration in the energy balance brings about radiative forcings (IPCC, 2007) which result in climate change - changes in the intensity, frequency, and variability of elements of climate: temperature, rainfall, humidity, solar radiation and airflow - as well as the tendency for extreme events: heat waves, tornados, floods, erosions, drought, etc.(IPCC, 2007; Hatfield et al., 2008; Stone et al., 2008). The anthropogenic GHGs and the processes that increase their emission, reduce their sequestration and change surface albedos (the reflectivity of surfaces) (Pielke, 2005; IPCC, 2007) are the drivers of climate change (IPCC, 2007; Ramanathan and Carmichael, 2008; UNEP, 2009). The GHGs have differential GHE and global warming potentials (GWP). In terms of natural GHE, water vapour is the most important GHG but in terms of anthropogenic GHE, $\mathrm{CO}_{2}$ is the most important (Paustian et al., 2006; Steinfeld et al., 2006; IPCC, 2007; Koneswaran and Nierenberg, 2008). However, for ability to absorb long wave radiation (global warming potential, GWP) the halocarbons are the most important. Table 1 contains the anthropogenic GHGs, their relative GHE and GWP. 
Table 1: GHE and GWP of Anthropogenic GHGs

\begin{tabular}{llcc}
\hline \multicolumn{1}{c}{ Gas } & Formular & GHE $(\%)$ & Relative $\mathrm{GWP} / \mathrm{CO}_{2}(100$ years $)$ \\
\hline Carbon dioxide & $\mathrm{CO}_{2}$ & 55 & 1 \\
Methane & $\mathrm{CH}_{4}$ & 15 & 25 \\
Halocarbons & $\mathrm{C}_{\mathrm{x}} \mathrm{H}_{\mathrm{y}} \mathrm{Hal}_{\mathrm{z}}$ & 10 & $\mathrm{NA}$ \\
i. Perfluorocarbons & $\mathrm{C}_{\mathrm{n}} \mathrm{F}_{\mathrm{n}}+2$ & $\mathrm{NA}$ & $7400-12200$ \\
ii. Hydrofluorocarbons & $\mathrm{C}_{\mathrm{n}} \mathrm{H}_{\mathrm{m}} \mathrm{F}_{\mathrm{P}}$ & $\mathrm{NA}$ & $120-14800$ \\
iii. Sulfur hexafluoride & $\mathrm{SF}_{6}$ & $\mathrm{NA}$ & 22800 \\
Nitrous oxide & $\mathrm{N}_{2} \mathrm{O}$ & 5 & 298 \\
Ozone & $\mathrm{O}_{3}$ & 10 & $\mathrm{NA}$ \\
\hline
\end{tabular}

Source: IPCC (2007); Manicore (2007); NA: Not available; N.B: Water vapour is not included because anthropogenic influence is negligible (Manicore, 2007).

Climate Models and Emission Scenarios: Simulating the impact of climate change

The potential impacts of climate change on livestock and other agricultural systems are best appreciated through simulation studies and modeling of future climates (Thompson and Pollard, 1995; Valtorta, 2002; Hatfield et al., 2008). Climate change scenarios can be modeled in order to observe and set realistic range of impacts bound by high and low climate extremes with a defined probability distribution. Modeling the impacts of climate on livestock based on realistic climate projections will provide a baseline to understand the consequences of climate variability as well as enable stakeholders integrate climate change adaptation measures in livestock enterprises (Da Silva, 2000a; Valtorta, 2002; Hatfield et al., 2008). Fortunately, a number of organizational modeling systems are currently in place and have generally been improving in efficiency thereby increasing the reliability of emission scenarios and climate change projections (IPCC, 2007). Numerous experiments in which temperature, carbon dioxide, ozone and other factors were varied have been conducted to compare current trends with projected scenarios (Schlesinger and Zhao, 1989; Morgan et al., 2003; 2004; Boote et al., 2005; AIACC, 2006; Morghan et al., 2006; Lobel and Field, 2007; Smith, 2008; Tietjen et al., 2010). Most models of climate change predict higher maximum temperatures and more hot days, more intense but variable and fewer precipitation events, higher minimum temperatures and fewer cold days, reduced diurnal temperature range, continental drying in some areas and associated drought risks (Mader et al., 2006; IPCC, 2007; Koneswaran and Nierenberg, 2008; UNEP, 2009). It is projected that the global average surface air temperature will increase by the range $1.8^{0} \mathrm{C}$ to $4.0^{\circ} \mathrm{C}$ by 2100 (IPCC, 2007; Brown et al., 2008; IFAD, 2009). Cooler climates will experience greater and more rapid warming than the global average while warmer climates will experience lesser warming than the global average
(Hatfield et al., 2008). Globally, atmospheric water vapour and precipitation are estimated to increase with increase in global warming. Generally, cooler climates (middle and high altitudes) will experience increased precipitation during the cooler months while at low altitudes (tropical and subtropical regions), regional increases and decreases in rainfall are expected. Although the mean precipitation is predicted to increase, larger year-to-year variations are expected (UNEP, 2009). Changes in cryosphere (snow cover, ice cap and glacier) will involve continuous and widespread retreat as a result of ice melt run off and iceberg calving. By 2100 it is expected that global mean sea level will rise by the range $0.09 \mathrm{~m}$ to $0.88 \mathrm{~m}$ above the 1990 level due primarily to thermal expansion of the warmer oceans in addition to the melting of glaciers and ice sheets (IPCC, 2007; Topping, 2007; UNEP, 2009). The rising sea levels will impact negatively on low land populations (man, animals and crops) due to increased flooding forcing populations to move inland to higher grounds.

\section{Climate Change and Livestock Production in Nigeria}

Nigeria's climate mirrors the global climate in its complexity and division into sub climates ranging from the arid/sahel of the north to the humid rainforest of the south and between these the derived savanna and savanna ecosystems. Climate change and climate variability are, therefore, of considerable importance to animal agriculture in Nigeria. Climate affects animal production directly through the principal weather factors: temperature, humidity, solar radiation and airflow and indirectly through alterations in the nutritional environment and changes in the epidemiology and dynamics of livestock disease pathogens, pests and vectors (Valtorta, 2002; Baylis and Githeko, 2006; Rowlinson, 2008; IFAD, 2009). Climate change will, therefore, impact livestock production in Nigeria in ways 
that will most likely correspond with the models for humid and dry tropical climates (BNRCC, 2008) namely: the greater constraining of the already hampered economic viability and sustainability of livestock production.

Indirect Impacts of Climate Change on Livestock Production Availability, Quantity and Quality of Livestock feed resouced

Sustainable livestock (farm animal) production rely heavily on the availability of livestock feed crops. Profitable ruminant animal production in intensive holdings, on pasture and range lands depend on the availability of quality grains and forages in enough quantities (Hatfield et al., 2008). Key quality parameters include fiber content, crude protein, mineral, non-structural carbohydrates and secondary toxic compounds and these will vary under different climate scenarios (Ainsworth and Long, 2005; Boote et al., 2005 AIACC, 2006; FAO, 2009). Yield responses under increased warming will vary, with species of grain crops according to each crops cardinal temperature requirement (Prasad et al., 2003; Reddy et al., 2005; Lobel and Field, 2007; Hatfield et al., 2008). Crops that have optimal range at cooler temperatures will exhibit significant decreases in yield as temperature increases above the upper range. The response to rising temperatures by grain crops may however, be more complicated because biological response to temperature is nonlinear and linear changes in temperature do not produce linear responses (Hatfield et al., 2008). Again, under the global climate change scenarios, many climate change factors interact to affect a biological entity. For instance, higher temperatures are often associated with decreases or lack of rainfall in many sub climates and this complication can exacerbate the effects of rising temperature (Hatfield et al., 2008).

Grain crops vary in their response to $\mathrm{CO}_{2}$ enrichment of the atmosphere according to whether they are carbon (III) $\left(\mathrm{C}_{3}\right)$ or carbon (IV) $\left(\mathrm{C}_{4}\right)$ crops. Simulation studies (Boote et al., 2005; Jifon and Wolfe, 2005; Ziska et al., 2005; Morgan et al., 2007) have shown that for most $\mathrm{C}_{3}$ crops (wheat, rice, legumes) there was significant increase in average yield under $\mathrm{CO}_{2}$ enrichment. The increase in yield was expressed as increased number of tillers-branches, panicles-pods, and number of seeds with minimal effect on seed size. Carbon (iv) crops (maize, millet, sorghum) increased their yield insignificantly under the same $\mathrm{CO}_{2}$ volume (Anderson et al., 2001). The beneficial effect of increased $\mathrm{CO}_{2}$ volume on yield is however, negated under elevated temperature (heat stress) at the reproductive phase of crops so that yield is compromised in the face of increased biomass accumulation (Newman et al., 2001; Jifon and Wolfe, 2005). Unrestricted root growth, optimum soil fertility and excellent control of weeds, pests, and diseases are also necessary to maximize the benefits of increased $\mathrm{CO}_{2}$ concentration (Newman et al., 2006).

The yield of forage and pasture crops $\left(\mathrm{C}_{3}\right.$ and $\mathrm{C}_{4}$ photosynthetic pathways) under different climate change scenarios is determine by the interaction between the major drivers of global climate change namely precipitation (rainfall), carbon dioxide and temperature. Field results, however, indicate that rainfall change was the explanatory variable in yield changes of both pasture and range-land forage crops followed by $\mathrm{CO}_{2}$ and temperature change (Izaurralde et al., 2003; Thomson et al., 2005). Reduced precipitation will lead to reduced yield since the overall ecology of pasture and range lands is determined by the spatial and temporal distribution of rainfall and consequences of precipitation patterns for soil water availability (Morgan, 2005; FAO, 2009; Tietjen et al., 2010). Rising $\mathrm{CO}_{2}$ in the atmosphere, warming (increase in temperature) and altered precipitation pattern all impact strongly on soil water content and plant water relations (Allen et al., 2003; Morgan et al., 2004b). Through simulation of photosynthesis and water use efficiency, rising $\mathrm{CO}_{2}$ was shown to enhance plant productivity on most range lands (Bond et al., 2003; Korner, 2006; Hatfield et al., 2008; Tietjen et al., 2010).

The sum of effects of atmospheric and climate change on forage quality is varied. Based on expected precipitation changes and known environmental effects on forage protein, carbohydrate, and fiber content, both positive and negative changes in forage quality are possible (Hatfield et al., 2008). Elevated $\mathrm{CO}_{2}$ volume can increase non-structural carbohydrate content of forage crops thereby enhancing forage quality. Nitrogen and crude protein content of forages are, however, reduced under $\mathrm{CO}_{2}$ enrichment of the atmosphere, especially, under poor soil nitrogen content (Cotrufo et al., 1998; Milchunas et al., 2005). This counters the positive effect of enhanced $\mathrm{CO}_{2}$ volume on plant production. The rising $\mathrm{CO}_{2}$ level, therefore, produces poorer forages which are poorly digested and utilized by ruminant animals. Experimental warming causes reduction in tissue nitrogen concentration. Thus, under increased environmental temperature and reduced rainfall (the likely situation in the field), forage quality is expected to decline and will 
produce negative effects on animal growth, reproduction and health (Milchunas et al., 2005). This could render livestock production unsustainable unless ruminant diets are supplemented with nitrogen sources. Ruminants require forages with at least $17 \%$ crude protein for maintenance, $10-14 \%$ for growth, and $15 \%$ for lactation. Optimal rumen fermentation also requires a balance between ruminally available protein and energy. The rate at which digester passes through the rumen decreases with increasing fiber content of forages (Hatfield et al., 2008). Tropical forages are essentially of the poor quality carbon (IV) type and increased warming will lead to greater deterioration of tropical forages (Valtorta, 2002; Hatfield et al., 2008).

\section{Climate change and diseases and pests of livestock}

Among the many factors that will affect the impacts of infectious livestock diseases in future is climate change (Baylis and Githeko, 2006). Many studies (Beaneth et al., 1999; Purse et al., 2004; Benneth and Lipelaar, 2005; Black and Nunn, 2009) have linked outbreaks of endemic, emerging and re-emerging animal diseases as well as the appearance of new transmission modes to climate change and there is general consensus that future climates will significantly impact the incidence, spread and pathogenic effects of livestock diseases (Rowlinson, 2008; Black and Nunn, 2009; IFAD, 2009). Under the variable Nigerian climate these impacts will not only vary according to pathogen, pest and vector type, but also from one region to another. Weather and climate affect disease pathogens in a complex and varied manner (Baylis and Githeko, 2006; de La Rocque et al., 2008; Black and Nunn, 2009). Climate may determine the spatial and temporal distribution of a disease pathogen (or pest) and/or its vector while weather may influence or determine the timing of outbreaks as well as its intensity (Baylis and Githeko, 2006). Disease pathogens and pests also vary in their environmental requirements for survival, multiplication and spread hence their response to climate change will depend on the adequacy (or otherwise) of these requirements as well as their adaptive potential to the changing climatic factors. Pathogens sensitive to temperature and moisture will either be enhanced or limited. Generally, pathogens favoured by warmer temperatures and high moisture will be enhanced by a warmer and wetter Nigerian climate. A drier and warmer climate will however limit most pathogens due to desiccation (Baylis and Githeko, 2006).
Climate change may also exert its effect by shortening or lengthening of seasons thereby influencing the life cycles of pathogens, pests and/or their vector hosts. Lengthening of warmer and wetter seasons will generally favour early developmental stages of these organisms, shorten their generation interval, increase the number of generations per year and enhance disease spread. The converse will be the case if the cold and drier seasons are lengthened (Harvell et al., 2002; Baylis and Githeko, 2006).

The animal hosts of disease pathogens may also be influenced by changes in climate and thus alter the existing host-pathogen relationship. Under the climate change scenario of increased warming due to the depletion of the ozone layer, animals may be exposed to doses of ultra violet radiation leading to cellular damage and depression of their cellular immune factors (eg. The T helper I Lymphocytes) as well as alter the normal cellular responses to vaccination (de Gruiji et al., 2003; Thomson et al., 2004). Animals thermally challenged may also be compromised immunologically making them more susceptible to diseases (Eisler et al., 2003; Thomson et al., 2004).

Both vector and non-vector borne animal diseases are influenced by weather and climate. The vectors of an animal disease must survive, multiply, spread, attack infected and susceptible hosts in order to effectively transmit the disease pathogen. A broad array of vectors: tabanids, muscides, flies (myiasis and tse-tse flies), fleas, ticks, mosquitoes, molluscs, etc transmit animal diseases. Climate impacts the epidemiological dynamics of these vectors principally through temperature and moisture. Climate warming and increased wetting may render areas which hitherto were too cold and/or dry for any of these vectors conducive and so expose their animal populations to new pathogen challenges (e.g. the expansion of tse tse belt to northern Nigeria) (BNRCC, 2008). On the other hand, regions that become less conducive to vectors may experience emigration of vectors whose population and challenge will consequently be reduced and so the diseases they transmit (Kovats, 2000; Gagnon et al., 2002; Baylis and Githeko, 2006). Climate instigates seasonal movement of vectors and changes in vector presence in different environments, thereby influencing the dynamics of animal diseases and pests (Davis et al., 1998; Harvell et al., 2002).

Non - vector animal diseases must also survive for a reasonable period outside the host and in the environment to infect a suitable (susceptible) host. Disease pathogens are 
differentially equipped for life outside their hosts. Spore forming animal disease pathogens generally survive better in their environment than non-spore forming organisms. For instance, spore forming Bacillus anthracis (causes anthrax in most warmblooded animals) and Clostridia organisms (cause blackleg in cattle) can remain infective for many years in pasture (Hall, 1988; Parker et al., 2002) while the non-spore forming Dermatophilus congolensis (causes dematophilosis in cattle) and Pasteurella multocida (causes pasteurellosis in bovines) have shorter environmental life span (in months) (Hall, 1988; Baylis and Githeko, 2006; Parker et al., 2002). Most viral infections that spread by infectious droplets (aerosol etc) or by direct contact between infected and susceptible hosts in close proximity (e.g. within a herd or within intensive holdings) such as the viruses that cause foot-and-mouth disease in cattle, sheep and pig; Pestes de petit ruminantes (PPR) in small ruminants; cattle rhiderpest, etc survive poorly outside the host and under harsh climates (Wosu et al., 1992; Sutmoller et al., 2003). These diseases are climate and weather dependent and outbreaks are usually associated with periods of high humidity (especially onset of rainy season) and dry cold periods. Some other non-vector and nonspore forming animal disease pathogens such as those that cause brucellosis, Avian influenza, rabies, salmonellosis, etc are less climate and weather dependent (Baylis and Githeko, 2006).

Parasitic diseases also differ in their environmental requirements to remain infective outside the host. For instance, the nematode, Haemonchus contotus (causes haemonchosis in cattle and sheep) requires warm temperature and adequate moisture for eggs and larvae to survive in the environment until ingested by another host. The trematode, Fasciola gigantica, (causes fascioliasis in cattle and sheep) uses snail intermediate hosts (Lymnacid snails) to survive and remain infective outside the primary host. Lymnacid snails depend on availability of low, wet pasture lands and flood plains or water pools to survive and multiply (Hall, 1988).

Vector-borne animal diseases spread by the effective contact and active interaction between the infected vector and a susceptible host. The interaction between a vector and its host environment as well as the impact of climate change on the vector will not only influence the spread of the pathogen but its intensity and impact. For instance, the vector transmitted bluetongue virus (causes bluetongue disease in sheep), and African horse sickness virus, transmitted by biting midge (genus Culicoides) (Baylis et al., 1999;
Purse et al., 2005), rift valley fever virus (a zoonotic disease of sheep and cattle), west nile fever virus (birds) and several viral encephalitidis of horses, transmitted by the Aedes and culex mosquitoes (Weaver and Berrett, 2004) all depend on the spatial and temporal distribution of the vector which is highly sensitive to climate variables (Limithicum et al., 1999; Mellor et al., 2000; Anyamba et al., 2002). Outbreaks of most of these diseases are associated with periods of combined heavy rainfall (following drought), flood, high temperatures, low or high humidity and increase in wind intensity. Tse-tse flies (the vector of the protozoan disease trypanosomiasis), ticks (vectors of anaplasmosis, babesiosis, heart-water, East coast fever etc), fleas as well as mites are highly climate dependent both as vectors and as pests. Generally, many aspects of vector's life cycles are sensitive to climate and spatial distribution are largely dependent on climate variables. Warm, wet climates generally favour their survival, multiplication, spread and impact both as vectors and as parasites (Rogers and Randolph, 1993).

Climate also influences the time period required for a vector to feed on an infected host and transmit the infection onward to a susceptible host (the extrinsic incubation period - EIP). The EIP of some vectors are temperature dependent (Baylis and Githeko, 2006). Under cold weather, the EIP is lengthened and some short-lived vectors, such as mosquitoes and biting flies, tend to die before the EIP is complete and so disease transmission does not occur (Reeves et al., 1994).

In conclusion, the relationship, association and impact of climate change on animal disease pathogens, pests and their vectors are very complex and variable. The short review presented above is meant to demonstrate this complexity and is by no means exhaustive. There is enough evidence to show that climate change has brought about changes in the dynamics of animal disease pathogens and vectors in recent years. The re-emergence of bovine tuberculosis in the United Kingdom (White et al., 1993), bluetongue disease in Europe in 1998 (the first in 20 years), and the expansion of the trypanosomiasis belt to northern Nigeria (BNRCC, 2008) are cases in point. Under the variable future climate scenarios (BNRCC, 2008; SEI, 2008), these impacts will not only vary according to pathogen, pest and vector type, but also from one region to another. Increased warming of different rates across the zones, increase in precipitation for some zones for some months followed by drought and drought alternating with periods of heavy rains 
in most zones (a pattern that encourages bouts of disease outbreaks), the future impact of animal diseases and pests on livestock production in Nigeria will not only be more severe but also unpredictable - a situation that will be made worse by poverty and lack of technology (IPCC, 2007).

\section{Direct Impact of Climate Change on Livestock Production}

Ambient temperature, humidity, wind speed, thermal radiation and precipitation are the major climate parameters which constitute the thermal environment and which are the potential environmental stressors of livestocks with regards to health, growth, yield and reproduction (Da Silva, 2000a; Hahn et al., 2003; Nardone et al., 2006; Nienaber and Hahn, 2007; Svotwa et al., 2007). There are levels of vulnerability associated with livestock production to the potential risks due to global warming (Hahn, 1995; Hatfield, 2009). These levels are associated with levels of productivity (Hatfield, 2009) as well as other environmental factors and genetic attributes of individual animals, species and breeds. As performance levels increase, the vulnerability of the animal increases and, when coupled with other adverse environmental factors (e.g. poor nutrition), the animal is at greater risk (Hatfield, 2009). Inherent genetic characteristics or management scenarios that limit the animal's ability to adapt to or cope with thermal stress also put the animal at risk. At high performance levels, any environment other than near optimum may put the animal at greater risk (Armstrong, 1994; Valtorta, 2002; Marai and Rashwan, 2004; Hatfield, 2009; Mader et al., 2009).

\section{Evaluating the thermal environment of the animal}

There is a range of temperature conditions (thermoneutral zone or optimal zone) within which animals are able to maintain a relatively stable body temperature without significantly altering behavioural or physiological function (Frank et al., 2004). Visible signs of thermal stress: panting, urination, salivation, sweating etc become apparent under severe heat stress. An empirical and sensitive measure is hence required to properly assess the thermal environment of the animal at all times. Evaluation of air temperature alone does not permit an accurate assessment of the effects of the thermal environment on physiology, welfare, health and productivity in farm animals (Segnalini and Nardone, 2010). High humidity reduces heat loss from the body by evaporation, while solar radiation adds to the heat from metabolic processes, thereby increasing the body heat load (Da Silva, 2000a; Valtorta, 2002; Sevi et al., 2002; West, 2003; Frank et al., 2004; Marai and Rashwan, 2004; Segnalini and Nardone, 2010). Air movement effectively facilitates dissipation of heat through convection and evaporation only within certain temperature ranges (Mawson and White, 1971). The extent of heat stress on animals depends on the combination of these factors, the duration for which a given combination exists and the adaptability of the individual animal. Consequently, a number of integrative measures have been developed (Da Silva 2000b; McGovern and Bruce, 2000; Turnpenny, 2000a; b), resulting in various thermal indices for different climatic zones, various animals and for different functions (Da silva, 2000a; Hahn et al., 2003; Eigenberg et al., 2005; Mader et al., 2006; Mitchell et al., 2001; Gaughan et al., 2002). Temperature and humidity are, however, the two most critical weather factors that impact livestock production directly and are essentially in focus when climate change induced weather effects on livestock are under consideration (Valtorta, 2002; Hatfield et al., 2008; Hatfield, 2009). Thus of the various thermal indices, the temperature humidity index (THI) (developed using the relationship between ambient temperature and relative humidity) is most popular (Hatfield, 2009) and represents the effect produced by the heat exchange process, which can alter the biological response that might be associated with changes in temperature alone and which impact performance, health and well being. The THI aims to support rational environmental management decisions related to animal welfare. It sets the upper limit beyond which animals show signs of heat stress. The intensity of heat stress as well as how long it lasts or the length of time (hrs) it takes the animal to recover from its effects is important in determining animal response (Hahn et al., 2003). This will normally vary with season, being longer during the hottest months of the year. Under the projected increased warming scenario, this means that the already hampered livestock performance in Nigeria will be further worsened. THI can be calculated by a variety of methods depending on the region of application (Bouraoui et al., 2002; Bohmanova et al., 2007; Vitali et al., 2009; Segnalini and Nardone, 2010). Variables mostly required include wet bulb temperature, dry bulb temperature, dew point temperature, ambient temperature, and relative humidity. Silanikove (2000) gave the formular for THI as $\mathrm{THI}=$ 0.72 $\left(\mathrm{W}^{\circ} \mathrm{C}+\mathrm{D}^{\circ} \mathrm{C}\right)+40.6$. Where, $\mathrm{W}^{\circ} \mathrm{C}$ and $\mathrm{D}^{\circ} \mathrm{C}$ refer to wetbulb and drybulb temperatures, 
respectively. Segnalini and Nardone (2010) calculated THI for a subtropical climate using the expression: $\mathrm{THI}=(1.8 \times \mathrm{AT}+32)-(0.55-0.55 \mathrm{x}$ $\mathrm{RH}) \times[(1.8 \times \mathrm{AT}+32)-58]$. Where, AT and RH refers to ambient temperature and relative humidity, respectively. Reports of Values of THI for cattle in the tropics (Valtorta, 2002; Foster et al., 2009) classified THI $\leq 70$ as normal (comfort or thermo-neutral zone), $71-78$ as alert (heat stress) and $79-83$ as danger (fatal zone). Dairy cattle in the tropics has been reported to show signs of heat stress when the THI is higher than 72 (Valtorta, 2002) or 74.2 (Svotwa et al., 2007).

\section{Effects of elevated temperature on performance of farm animals}

Voluntary feed intake; feed conversion ration, body weight gain and age at maturity are some of the performance traits affected by thermal stress. Voluntary feed intake (VFI) is the primary factor influencing the production capacity of livestock (Mader and Davis, 2004). Accurate assessment of feed consumption under heat stress is therefore, a prerequisite for accurate evaluation of changes in production resulting from changes to a warmer climate. In doing this other factors which affect VFI such as the breed of animal, age, sex, health status and management practices must be taken into consideration (Strickhin, 1986; Laudert, 1995; Graylean and Hubbert, 1995; Mader et al., 2009). Thermal stress alters the acquisition of potentially absorbable nutrients and energy. The onset of thermal stress results in decline in eating and grazing activities reducing voluntary feed intake (Hatfield, 2009). Dry matter intake is most severely reduced. There is also decrease in the rate of passage of digester through the digestive tract resulting in increase in digestibility (Beede and Collier, 1986; Hahn, et al., 2003; Mader et al., 2009). However, a concomitant reduction in the rate of nutrient absorption from the gut offsets the benefits of increased digestibility so that there is a net reduction in nutrient availability to the animal. Meanwhile, there is increased demand for maintenance occasioned by emergency physiological intervention to restore normothermia and homeostasis (Valtorta, 2002, Mader et al., 2009). These physiological responses and their hormonal precursors alter the metabolism of absorbed energy substrates and nutrients requiring concerted intervention to help the animal cope with heat-stress, maintain health and performance. Body weight, body condition and level of productivity affect the magnitude of voluntary feed intake and the ambient temperature at which changes in VFI begin to be observed (Mader et al.,
2009). Reduction in voluntary feed intake is accompanied by decreases in feed utilization efficiency, rate of body weight gain and general decline in performance (Milk yield, reproduction etc) (Armstrong, 1994; Hahn, et al., 2003; Rowlinson, 2008; Mader et al., 2009). Studies evaluating climate change impact on productive traits of farm animals in Nigeria are scarce, however, reports based on simulation studies elsewhere indicate losses in production due to thermal stress. For instance Mader et al., (2009) using two future climate scenarios (doubled $\mathrm{CO}_{2}$ by 2040 and tripled $\mathrm{CO}_{2}$ by 2090) studied changes in production performance in swine, dairy and beef cattle in the great plain of U.S.A. Day-to-slaughter weight increased by an average of 3.7 days from a base line of 61.2 days in pigs. The potential annual loses, averaged $6 \%$ or 12.4 million US dollars. For beef cattle, day-to-slaughter weight increased by 4.8 days above the 127 days base line or $3.8 \%$ loss, costing producers about 43.9 million US dollars annually. For dairy production, 2.2\% $(105.7 \mathrm{~kg}$ milk/cow) reduction in milk production was projected at a cost of 28 million US dollars annually. Some other studies reported similar performance losses in cattle (Sprott et al., 2001; Frank et al., 2004; Mader et al., 2006; Amundson, et al., 2006; Mader et al., 2009), in small ruminants (Dixon et al., 1999; Silanikove, 2000; Sevi et al., 2002), in pigs (Ricalde and Lean, 2000; Huynh et al., 2005; Lin et al., 2005), in poultry (defra, 2005; Mohan, 2005; Al-Ghamdi, 2008; Attia et al., 2009; Minka and Ayo, 2010), in rabbits (Marai et al., 2002; Marai and Rashwan, 2004) and in buffalos (Vale, 2007).

\section{Adaptation Measures}

Climate warming results in an increase of heat stress in Nigeria (BNRCC, 2008). Therefore, all methods to help animals cope with heat stress would be useful to adapt to the impacts of climate warming. A number of basic management schemes for reducing the effects of thermal stress have been suggested (Valtorta, 2002; Lin et al., 2005; Gwatibaya et al., 2007; Thornton et al., 2008; Sidahmed, 2008; IFAD, 2009). The three main schemes are: physical modification of the environment, genetic development of less sensitive breeds and improved nutritional management schemes.

Physical modification of the environment to relieve heat stress would include provision of shades, ventilation cooling, and combination of ventilation and sprinkling. Provision of shades is the simplest method (Armstrong, 1994; Valtorta, 2002; Shearer et al., 2002; Epperson, 2003) to 
reduce the impact of high solar radiation on extensively or semi-intensively managed livestock. Shades can be either natural or artificial, permanent or moveable (Gwatibaya et al., 2007). Tree shades have proved the more efficient (Hahn, 1985; Armstrong, 1994; Hahn, 1982, Valtorta, 2002) because they combine protection from solar radiation with the radiation sink effect created by cool leaves evaporating moisture. To enhance the availability and utilization of natural shades would involve the conservation of nature and ecosystems and modifying stock routing and distances (Thornton et al., 2008; IFAD, 2009). When enough natural shading is not available artificial structures may be erected. Corrugated steel roofing sheet and asbestos are popular for roofing of shades because of cost, durability and low maintenance requirement. However, in the tropics many natural roofing materials are available all year round and thatch grasses are good shading materials. Animals that have access to shade present lower rectal temperatures and higher (stable) performance than animals without shade (Hahn et al., 2003). The orientation of the shade represent a compromise between most effective shading for the animals and maintenance of dry ground in the shade. If rainfall is substantial, a north-south orientation will be preferred to take advantage of early morning and afternoon sun to dry the shade. If rainfall is scanty, then the eastwest orientation will be preferred (Armstrong, 1994). The best way to implement shading of livestock is to adopt mixed livestock farming systems such as stall-feed and/or milking system and pasture grazing (IFAD, 2009). Nomadic livestock husbandry requires that shades be moveable or that permanent shades should be provided along stock routes.

Ventilation cooling involving air movement is an important intervention to relieve heat stress since it enhances convection and, depending on air humidity, evaporative heat losses (Valtorta, 2002; Sevi et al., 2002; Pennington et al., 2004). In the tropics, natural ventilation are maximized by constructing open sided houses. Forced ventilation using large fans will be very beneficial especially during the hottest months of the year. Wetting and ventilation involve the provision of sprinklers and large fans in the holding pens or milking parlour. Spray evaporative cooling comes in various methods and designs (Hahn, 1985; Armstrong and Wiersma, 1986; Schultz, 1988, Turner et al., 1989; Armstrong, 1994; Sevi et al., 2002; Valtorta, 2002). The use of a sprinkler and fan system, for 30 minutes before milking, proved useful to relief dairy cows of heat stress, in terms of efficiency to reduce the impact of heat waves under a grazing system (Valtorta, 2002).

The use of breeding strategies to adapt to climate change involve the long term selection of animals with proven genetic ability to combine tolerance of hotter environments and greater challenges of diseases and parasites with high productivity (Hoffmann, 2008; IFAD, 2009). In this regard identifying and strengthening of local breeds that have adapted to local climatic stress; improving local breeds by cross breeding with heat and disease resistant breeds will constitute future beneficial adaptation strategies (Hoffmann, 2008). The introduction of livestock insurance systems, early warning systems and other forecasting and crisis-preparedness systems could also benefit adaptations efforts (IFAD, 2009).

Modification of the nutritional environment of an animal as an adaptation strategy for thermal stress, aims to ameliorate the negative impact of thermal stress on nutrient acquisition, digestion, absorption and utilization (Silanikove, 2000; Renaudean et al., 2005; Gwatibaya et al., 2007). The principal nutrients needed by an animal for normal production need to be adjusted to take care of shortages as a result of the reduction in voluntary intake as well as reduced absorption from the alimentary canal. Digestible energy can be increased by providing energy concentrates (grains and fat) while reducing fiber content by reduction in forage component of the ration. In this way, body heat production is reduced by reducing rumen fermentation heat (Beede and Collier, 1986; Silanikove, 2000; Linn et al., 2004; Pennington et al., 2004). Supplemental protein, vitamins and minerals should also be provided as these are concomitantly available at levels short of requirements for normal function (Beede and Collier, 1986; Gwatibaya et al., 2007). Sodium, potassium, magnesium, calcium and chlorine are particularly critical as these are excreted particularly in sweat in large amounts during thermal stress (Silanikove, 2000; Gwatibaya et al., 2007). Supplementary minerals are also required to maintain the osmotic gradient needed to move water through pools of cellular fluids to the evaporatory surfaces (Beede and collier, 1986; Schneider et al., 1986). Water is the most important nutrient in minimizing heat stress because it acts as a heat sink (Linn et al., 2004). This in addition to the increased loss of body water through urine, sweat and respiratory evaporation to reduce heat load account for the increase in water consumption (up to 2 folds) observed during heat stress (Pennington et al., 2004; Gwatibaya et al., 
2007). Animals under heat stress should, therefore, be given unlimited access to cool clean water. Thermal stress causes alterations in the acid-base balance leading to imbalances in blood acid-base plus a decrease in the salivary bicarbonate pool available for rumen buffering (Beede and Collier, 1986; Silanikove, 2000). Consequently, rumen $\mathrm{pH}$ drops while blood $\mathrm{pH}$ may rise (alkalosis) (Schneider et al., 1986). Supplementation of an acetogenic agent (e.g. Ammonium chloride or ammonium sulphate) to correct alkalosis and sodium bicarbonate to buffer the rumen will also be beneficial (Silanikove, 2000).

\section{CONCLUSION}

The most critical issues as it concerns proper understanding of the mechanisms of atmospheric GHE, the impacts of anthropogenic GHGs on global warming, relative importance of GHGs to global warming (GW) and the projected impacts of GW on livestock production in Nigeria using results of global and African climate change models and scenarios. The over whelming evidence suggests an impending climate induced catastrophic events in the African continent (Nigeria inclusive) with regards to growth and sustainability in the livestock sector. The potentials for sudden extreme weather events (heat waves, tornadoes, windstorm, rainstorm, coastal flooding, erosion and soil degradation) observed in some regions of the world require that a concerted effort be made to create awareness as well as instigate proactive measures to meet these challenges. Preliminary studies evaluating the vulnerability of various sectors of the Nigerian economy to climate change effects (BNRCC, 2008) showed that virtually all of the sectors analyzed manifest evidence of vulnerability to climate change. The poverty level in Africa coupled with the lack of requisite technology to check emergences means that livestock farmers in Nigeria will be seriously affected by the adverse effects of climate change unless appropriate proactive adaptation and mitigation measures are taken.

\section{REFERENCE}

AIACC (2006).Climate change and variability in the mixed crop/livestock production systems of the Argentinean Brazilian and Uruguayan pampas. Final Report (Gimenez, A.(ed). The International START Secretariat, 2000 Florida Avenue, NW Washington, DC 20009 USA.

Ainsworth, E.A. and Long, S.P. (2005). What have we learned from 15 years of free - air $\mathrm{Co}_{2}$ enrichment (FACE)? A meta-analytic review of the responses of photosynthesis, canopy, New phytologist 165: $351-371$.

Al-Ghamdi, Z.H. (2008). Effects of commutative heat stress on immunoresponse in broilers chickens Reared in closed system. International Journal of Poultry Science 7 (10): $964-968$.

Allen, L. H. Jr., Pan, D., Boote, K. J., Pickering, N. B. and Jones, J. W. (2003). Carbon dioxide and temperature effects on evapotranspiration and water-use efficiency of soybean. Agronomy Journal, 95, 10711081.

Amundson, J. L., Mader, T. L., Rasby, R. J. and $\mathrm{Hu}$, Q. S. (2006). Environmental effect on pregnancy rate in beef cattle. Journal of Animal Science, 84, 3415-3420.

Anderson, I.J., Maherali, H., Johnson, H.B., Polley, H.W., Jackson, R.B. (2001). Gas exchange and photosynthetic acclimation over subambient to elevated $\mathrm{Co}_{2}$ in a $\mathrm{C}_{3}-$ $\mathrm{C}_{4}$ grassland. Global change Biology 7: 693 -707 .

Anyamba, A., Limithicum, K.J., Mahoney, R., Tucker, C.J. and Kelley P.W. (2002). Mapping potential risk of Rift Valley fever outbreaks in African savannas vegetation index time series data. Photogrammetric Engineering and Renote Sensing 68, 137 45.

Armstrong, D. and Wiersma, F. (1986). An update on cow cooling methods in the West. ASAE paper No. 86 - 4034. ASAE, St. Joseph, M.I.USA.

Armstrong, D.V. (1994). Heat stress interaction with shade and cooling. In: Symposium: Nutrition and heat stress. J. Dairy Sci. 77: 2044 - 2050.

Attia, Y.A., Hassan, R.A. and Qota, E.M. (2009). Recovery from adverse effects of eat stress on slow-growing chicks in the tropics: Effects of ascorbic acid and diff levels of betaine. Trop. Anim. Health Prod. 41 (5): $807-818$.

Baylis, M. and Githeko, A.K. (2006). The effects of climate change on infections Diseases of animals. Report of T7.3 Foresight: Infections diseases preparing for the future.

Climate Change and Livestock Production in Nigeria online at www.foresight.gov.uk.

Baylis, M. Mellor, P.S. and Meiswinkel, R. (1999). Horse sickness and ENSO in South Africa. Nature 397 - 574. 
Beede, D.K. and Collier, R.J. (1986). Potential nutritional strategies for intensively managed cattle during thermal stress. . Anim. Sci. 62: 543.

Bennett, R. and Lipelaar, J. (2005). Updated estimates of the costs associated thirty four endemic livestock diseases in Great Britain: A note. Journal of Agricultural Economics $56,135-144$.

Beanett, R.M., Christiansen, K. and CliftonHadley, R. S.(1999). Direct cost of epidemic diseases of farm animals in Great Britain, Veterinary Record 145, 376 - 377.

Black, P. and Nunn, M. (2009). Impact of climate change and environmental changes on emerging and re-merging animal diseases and animal production. $77^{\text {th }}$ General session International committee world organization for animal health Paris, 24 -29 May 2009.

BNRCC. (2008). Climate change in Nigeria: Vulnerability, Impacts and Adaptation. Available online at htt://www.nigeriaclimatecange.org/ccinfo.p hp.

Bohmanova, J. Misztal, I. and Cole, J.B. (2007). Temperature - Humidity Indices as indicators of milk production loses due to heat stress. J. Dairy Sci. 90: 1947 - 1956.

Bond, W.J., Midgley, G.F. and Woodward, F.I. (2003). The importance of low atmospheric $\mathrm{Co}_{2}$ and fire in promotion the spread of grasslands and savannas. Global change Biology 9: 973 - 982 .

Boote, K. J., Allen, L. H., Prasad, P. V. V., Baker, J. T., Gesch, R. W., Snyder, A. M., Pan, D. and Thomas, J. M. G. (2005). Elevated temperature and $\mathrm{CO}_{2}$ impacts on pollination, reproductive growth, and yield of several globally important crops. Journal of Agricultural Metereology, 60, 469-474

Bouraoui, R. Lahmar, M., Majdoub, A., Djemali, M., Belyea, R. (2002).The relationship of temperature - humidity index with milk production of dairy cows in a mediterranean climate. Anim. Res.51: 479 - 491.

Boyazoglu, J. (1998). Livestock farming as a factor of environmental, social and economic stability with special reference to research. Livest. Prod. Sci. 57, 1 - 14pp.

oyazoglu, J. (2000). Interaction of breeding and nutrition for efficient animal production. Arian Aus. J. Anim. Sci., 13, Special Issue, 7 - 11pp.

Boyazoglu, J. and Nardone, A. (2003). The relationship between environment and animal production. Arch. Latinoam. Prod. Anim. 11 (1): 57 - 64.

Brown, S.J., Caesar, J. and Ferro, C.A.T. (2008). Global changes in extreme daily temperature since 1950. Journal of Geophysical Research, 113, DO5115, doi:10. 1029/2006 JD008091.

Buchdahl, J. M. C.(2002). Climate change: Fact sheet series for key stage 4 and A - level. Atmosphere, climate and Environment Information Programme, aric. Manchester Metropolitan University, Chester Street, Manchester M1 5GD. Available online at http://www.ace.mniu.ac.uk/

Buchdahl, J.M. (1999). Global climate change student information guide. Atmospheric research and information centre, Manchester Metropolitan University, 98 pp.

Cotrufo, M. F., Ineson, P. and Scott, A. (1998). Elevated $\mathrm{CO}_{2}$ reduces the concentration of plant tissues. Global Change Biology, 4, 4354.

Da Silva, R.G. (2000a). Weather and climate and animal production. Climatology $\mathrm{CH}$. II. Available online at htt://www.wmo.int/pages/prog/wcp/agm/ga $\mathrm{mp} /$ document/chap11-draft.pdf.

Da Silva, R.G. (2000b). A model for the assessment of thermal balance of cattle in tropical environments. Brazilian J. Anim. Sci. 29, (4): $1244-1252$.

Davis, A.J., Jenkinson, L.S.,Lawton, J.H., Somocks, B. and Wood, S. (1998). Making mistakes when predicative sifts in species range in response to global warming. Nature $391,783-786$

de Gruiji, F.R., Longstreth, J., Norval, M., Cullen, A.P/. Slaper, H., Kripke, M.L., Takizawa, Y. and Van der Leun, J.C. (2003). Health effects from stratospheric ozone depletion and interaction with climate change. Photochemical and photobiological sciences $2,16-28$.

de la Rocque, S., Rioux, J.A. and Slingenbergh, J. (2008). Climate change: effects on animal disease systems surveillance and control. Rev. Sci. Tech. Off. Int. Epiz. 27, 339 354.

defra (2005). Heat stress in poultry: Solving the problem. The Department for Environment, Fc Nwosu C. C and Ogbu. C.C. Juse, 17 $\mathrm{Sn} \quad \mathrm{P}$ 3IR Available online at www.defra.gov.uk.

Dixon, R.M., Later, T.H.E., Thomas, R. and Holmes, J.H.G. (1999).Interaction between heat stress and nutrition in sheep fed 
roughage diets. J. Agric. Sci. 132: 251 359.

EC (2007). Land use change - a significant driver of climate change. In: science for environment policy. DG Environmental News Alert service, issue 12, European commission, March 2006.

Eigenberg, R. A., Brown-Brandl, T. M., Nienaber, J. A. and Hahn, G. L. (2005). Dynamic response indicators of heat stress in shaded and non-shaded feedlot cattle. Part 2: Predictive relationships. Biosystem Engineering, 91, 111-118.

Eisler, M.C., Torr, S.J., Coleman, P.G., Machila, N. and Morton, J.F. (2003). Integrated control of vector - borne diseases of livestock pyrethroids: panacea or poison? Trends in Parasitology 19, 341 - 345.

Epperson, B. (2003). Recommendations for cooling systems for dairy cattle. SDSU, Cooperative Etension service USDA.

FAO (2009). Review of evidence on drylands pastoral systems and climate change: Implications and opportunities for mitigation and adaptation (Neely, C., Bunmig, S. and Wilkes, A. eds.), Land and water discussion paper 8 . Land tenure and management unit (NRLA). Land and water Division.

Foster, L.A., Fourie, P.J. and Neser, F.W.C. (2009). Effect of heat stress on six beef breeds in the Zastron district: The significance of breed, coat colour and coat type. South African Journal of Animal Science 39 (Suppl. 1): $224-228$.

Frank, K.L., Mader, T.L., Harrington, J.A. Jr., and Hahn, G.L. (2004). Potential climate change effects on warm - season livestock production in the Great Plains. Journal series no. 14462, Agric. Res. Div. University of Nebraska.

Gagnon, A.S., Smoyer - tomic, K.E. and Bush, A.B.G. (2002). The ElNino Southern Oscillation and Malaria epidemics in South America. International Journal of Biometeorology 46, $81-89$.

Gaughan, J.G., Goopy, J. and Spark, J.(2002). Excessive heat load index for feed lot cattle. In: Meat and livestock - Australia Project Report, FLOT. 316. MLA Ltd, Sydney, NSW.

Graylean, M.L. and Hubbert, M.E. (1995).Effects of season, health and management on feed intake by beef cattle. In: Symposium: Intake by feedlot cattle, Oklahoma Agric. Exp.
Station, Oklahoma State University, Stillwater, Ok, pp.226- 234.

Gwatibaya, S., Svotwa, E. and Jambwa, D. (2007). Potential effects of management options for heat stress in Diary cows in Zimbabwe: A Review. Electronic Journal of Environmental, Agricultural and food chemistry, 6 (5), 2066 - 2074.

Hahn, G. L. (1995). Environmental management for improved livestock performance, health and well-being. Japanese Journal of Livestock Mangement, 30, 117-127.

Hahn, G.L.(1982). Compensatory performance in livestock: influences on environmental criteria. Livestock environment II: Proc. $22^{\text {nd }}$. International Environment Symposium. ASAE, St. Joseph, MI, pp. 285 $-294$.

Hahn, G.L., (1985). Management and housing of farm animals in hot environments. In: Stress physiology of livestock, 2 (M.K. Yousef, ed.), pp 151 - 174. CRC Press, Boca Raton, FL.

Hahn, G.L., Mader, T.I. and Eigenberg, R.A. (2003). Perspective on development of thermal indices for animal studies and management. In: Interactions between climate and animal production. EAAP Technical series No. 7, 31 - 44. Wagemigen Academic Publ., Wagemingen, The Netherlands.

Hahn, G.L., Mader, T.L. and Eigenberg, R.A. (2003). Perspective on development of thermal indices for animal studies and management, pp. 31044, In: Interactions between climate and animal production (Lacetera, N., Bernabucci, U., Khalifa, H.H., Ronchi, B. and Nardone, A. eds.,), EAAP Tech. Series No. 7, Wagenigen Academic Publishers, The Netherlands (ISSN 1570 - 7318).

Hall, A. E. (1992). Breeding for heat tolerance. P. 129-168. in: Plant breeding reviews. Vol. 10. john Wiley \& Sons, New York.

Hall, H.T.B. (1988). Diseases and parasites of livestock in the tropics. Longman scientific and technical: Harlow, Essex

Harvell, C.D., Mitchell, C.E., Ward, J.R., Altizer, S., Dobson, A.P. Ostfeld, R.S., and Samuel, M.D. (2002).Ecology - climate warming and disease risks for terrestrial and marine biota. Science 296, 2158- 2162.

Hatfield, J. L. (2009). The effects of Climate Change on Livestock Production. Production Management Feature Articles. Available on line at The pigsite.com 
Hatfield, J. L. (2009). The effects of Climate Change on Livestock Production. Production Management Feature Articles. Available on line at The pigsite.com

Hatfield, J., Boote, K., Fay, P., Hahn, L., Izaurralde, C., Kimball, B.A., Mader, T., Morgan, J., Ort, D., Polley, W., Thomson, A. and Wolfe, D. (2008). Agriculture. In: The effects of climate change on agriculture, land resources, water resources, and biodiversity. A Report by the U.S. Climate change science programme and the subcommittee on Global change Research, Washington, DC., USA, 362pp.

Hegeri, G.C., Zwiers, F.W., Braconnot, P., Gillet, N./P., Luo, Y., Marengo, Drsini, J.A., Nicholls, N., Penner, J.E. and Stott, P.A. (2007). Understanding and attributing climate change. In: Climate change 2007: The physical science basis. Contribution of Working Group 1to the fourth assessment report of the intergovernmental panel on climate change (Solomon, S., Qin, S., Manning, M., Chen, Z., Marquis, M., Averyt, K.B., Tignor, M. and Miller, H.L. (eds.). Cambridge University Press, Cambridge, United Kingdom and New York, NY, USA>

Hoffmann, I. (2008). Livestock Genetic diversity and climate change Adaptation. Livestock and Global change conference proceeding May 2008, Tunisia.

Huynh, T.T.T., Aarnink, A.J.A, Verstegen, M.W.A., Gerrits, W.J.J., Heetkamp, M.J.W., Kemp, B. and Canh, T.T. (2005). Effects of increasing temperatures on physiological changes in pigs at different relative humidities. J.Anim. Sci.83: 1385 1396.

IFAD (2009). Livestock and climate change. Livestock thermatic papers. Available online at www.ifad.org/irkm/index.tm

IPCC. (2007). Climate Change 2007: The physical Science Basis. Contribution of Working Group 1 to the Third Assessment Report, Policy Maker Summary. Intergovernmental Panel on Climate Change. Cambridge University Press, Cambridge, UK.

IPCC. (2007). Climate Change 2007: The physical Science Basis. Contribution of Working Group 1 to the Third Assessment Report, Policy Maker Summary. Intergovernmental Panel on Climate Change. Cambridge University Press, Cambridge, UK.

Izaurralde, R. C., Rosenberg, N. J., Brown, R. A. and Thomson, A. M. (2003). Integrated assessment of Hardley Center climate change projections on water resources and agricultural productivity in 2030 and 2095. agricultural and Forest Metereorology, 117, 97-122.

Jifon, J. and Wolfe, D. W. (2005). High temperature-induced sink limitation alters growth and photosynthetic acclimation response to elevated $\mathrm{CO}_{2}$ in beans. Journal of the American Society for Horticultural Science, 130, 515-520.

Koneswaran, G. and Nierenberg, D. 92008). Global farm animal production and global warning: Impacting and mitigating climate change. Environmental health Perspectives, 116 (5): $578-582$.

Korner, C. (2006). Plant $\mathrm{Co}_{2}$ responses: an issue of definition; time and resource supply. New phytologist 172: $393-411$.

Kovats, R.S. (2000). El Nino and human health. Bulletin of the World Health Orgnaisation $78,1127-1135$.

Kronfeld, D.A., Donoghue, S., Naylor, J.M., Johnson, K. and Bradley, C.A. (1980). Metabolic effects of feeding protected tallow to dairy cows. J. Dairy Science 63: 545.

Laudert, S.B. (1995). Feeding behaviour of finishing steers. In: Symposium: Intake by Feedlot cattle. Oklahoma Agric. Expt. station, Oklahoma State University Stillwater, Ok, pp. 31 -35.

Limithicum, K.J., Anyamba, A., Tucker, C.J., Kelley, P.W., Myers, M.F. and Peters, C.J. (1999). Climate and satellite indicators to forecast Rift valley fever epidemics in Kenya. Science 285, $397-400$.

Lin, H., Jiao, H.C., Buyse, J. and Decuypere, E.(2005). Strategies for preventing heat stress in poultry. World's poultry science journal 62 (1): $71-86$.

Linn, J., Raeth-Knight, M. and Larson, R. (2004). Managing heat stress on lactating dairy cow. Hubbarb Feeds Inc.

Lobell, D. B. and Field, C. B. (2007). Global scale climate-crop yield relationship and the impact of recent warming. Environmental Research Letters, 2, 1-7.

Mader, T. L. and Davis, M. S. (2004). Effect of management strategies on reducing heat Nwosu C. C and Ogbu. C.C. I and water Science. 77, 2065-2072.

Mader, T. L., Davis, M. S. and Brown-Brandl, T. (2006). Environmental factors influencing 
heat stress in feedlot cattle. Journal of Animal Sciences, 84, 712-719.

Mader, T.L., Frank, K.L., Arrington Jr. J.A., Hahn, G.L. and Nienaber, J.A. (2009). Potential climate effects on warm season livestock production in the Greats plains. Climate change 97: $529-541$.

Manicore (2007). What are the greenhouse gases? Available online at www.manicore.com.

Marai, I.F. M and Rashwan, A.A. (2004). Rabbits behavioural response to climate and managerial conditions - a review. Arch. Tierz. Dummerstorf 47(5): 469 -482.

Marai, I.F.M., Ayyat, M.S., Gabr, H.A. and Abd EL-Monem, U.M. (1999). Growth performance, some blood metabolites and carcass traits of New Zealand white male rabbits as affected by heat stress and its alleviation under Egyptian conditions. Cahiers options mediterra-neennes 41, pp $35-42$.

Maria, I.F.M., Habeeb, B.A. and Gad, A.E. (2002). Rabbits' productive, reproductive and physiological performance traits as affected by heat stress. A review. Livest. Prod. Sci. 78, pp $71-90$.

Mawson, W.F.Y. and White, B.J. (1971). Climatic and Biological limitations to Diary production in a tropical environment. Tropical Grassland 15 (3): 145 - 157.

McGovern, R.E. and Bruce, J.M. (2000). A model of the thermal balance for cattle in hot conditions. J. Agric. Engng. Res. 77, No.1. pp. $81-92$.

Mellor, P.S., Boorman, J. and Baylis, M. (2000). Culicoides biting midges: their role as arbovirus vectors. Annual Review of Entomology 45, 307 - 340.

Minka, N.S. and Ayo, J.O. (2010). Modulating role of vitamins $\mathrm{C}$ and $\mathrm{E}$ against transport Induced stress in pullets during the Hot Dry conditions. Int. Scholarly doi:10.5402/2011/497138.

Milchunas, D. G., Mosier, A. R., Morgan, J. A., LeCain, D. R., King, J. Y. and Nelson, J. A. (2005). Elevated $\mathrm{CO}_{2}$ and defoliation effects on a shortgrass steppe: forage quality versus quantity for ruminants. Agriculture, Ecosystems and Environment, 111, 166184.

Mitchell, M. A., Kettlewell, P. J., Hunter, R. R., and Carlicle, A. J. (2001). Physiological stress response modeling - application in the broiler transport thermal environment. Proceedings $6^{\text {th }}$ international livestock environment symposium, American Society of Agricultural Engineers, St Joseph, Mi: 550-555.

Mohan, J. A.G. (2005).Physiology of stress poultry. Central Avian Research Institute, Izatnager (UP) - 243122.Poultvet.com.

Morgan , P. A., Mies, T. A., Bollero, G. A., Nelson, R. L. (2006). Season-long elevation of ozone concentration to projected 2050 levels under fully open-air conditions substantially degreases the growth and production of soyabean. New phytologist, 170,333-343.

Morgan, J. A. (2005). Rising atmospheric $\mathrm{CO}_{2}$ and global climate change: management implications for grazing lambs.pp.245-272 in: S. G. Reynolds and J. Frame (eds.) Grasslands: Developments Opportunities Perspectives. FAO and Science pub. Inc.

Morgan, J. A., Milchunas, D. G., LeCain, D. R., West, M. S. and Mosier, A. (2007). Carbon dioxide enrichment alters plant community structure and accelerates shrub growth in the shortgrass steppe. Proceedings of the National Academy of Sciences 104, 1472414729.

Morgan, J. A., Pataki, D. E., Korner, C., Clerk, H., Del Grosso, S.J., Grunzweig, J. M., Knapp, A. J., Mosier, A. R., Newton, P. C. D., Niklaus, P. A., Nippert, J. B., Nowak, R. S., Prton, W. J., Polly, H. W. and Shaw, M. R. (2004b). water relations in grassland and desert ecosystems exposed to elevated atmospheric $\mathrm{CO}_{2}$. oecologia, 140, 11-25.

Morgan, J.A., Pataki, D.E., Korner, C., Clark, H., Grosso, S.J.D., Grunzweig, J.M., Knapp, A.K., Mosier, A.R., Nweton, P.C.D, Niklaus, P.A., Nippert, J.B., Nowak, R.S., Parton, W.J., Polley, H.W. and Shaw, M.R. (2004). Water relations in grassland and desert ecosystems exposed to elevated atmospheric $\mathrm{Co}_{2}$. Oecologia 140: $11-25$.

Morgan, P. B., Ainsworth, E. A., and Long, S. P. (2003). How does elevated ozone impact soyabean? A meta-analysis of photosynthesis, growth and yield. Plant, Cell \& Environment, 26, 1317-1328.

Morgan, P. B., Bernacchi, C. J., Ort, D. R. and Long, S. P. (2004). An invivo analysis of the effect of season-long open-air elevation o ozone to anticipated 2050 levels on photosynthesis in soyabean. Plant Physiology, 135, 2348-2357.

Nardone, A. (2000). Weather conditions and genetics of breeding systems in the Medierranean area. Proc. $35^{\text {th }}$ Int. Symp. Of 
Societa Italiana peril Progressor della Zootecnia, Ragusa (It.) 67 - 91pp.

Nardone, A., Ronchi, B., Lacetera, N., and Bernabuci, U. (2006). Climate effects on productive traits in livestock. Vet. Res. Commun 30 91): $75-81$.

Newman, Y. C., Sollenberger, L. E., Boote, K. J., Allen, Jr. L. H. and Litell, R. C. (2001). Carbon dioxide and temperature effects on forage dry matter production. Crop Science, 41, 399-406.

Newman, Y. C., Sullenberger, L. E., Boote, K. J., Allen, Jr. L. H., Thomas, J. M. and Littell, R. C. (2006). Nitrogen fertilization affects bahiagrass response to elevated atmospheric carbon dioxide. Agronomy Journal, 98, 383-387.

Nienaber, J.A. and Hahn, G.L. (2007). Livestock production system management response to thermal challenge. Int.J. Biometeorol 52: 149 - 157 doi: 10. 1007/5004 84 - 007 $0103-\mathrm{x}$.

Paustian, K., Antle, M., Sheean, J. and Elder, P. (2006). Agricultures role in Greenhouse gas mitigation. Washington, DC. Pew centre on global climate change.

Parker, R., Mathis, C., Looper, M. and Sawyer, T. (2002). Anthrax and livestock. Guide B120. Cooperative Extension service, college of Agriculture and Home Economics, University of New Mexico: Las Cruces, New Mexico.

Pennington, J.A. and Van Devender, K. (2004).Heat stress in dairy cattle. UACES Publications.

Pielke, Sr. R.A. (2005). Land use and climate change. Science 310: 1625 - 1626.

Polley, H. W., Morgan, J. A., Campbell, B. D. and Stafford Smith, M. (2000). Crop ecosystem response to climate change: rangelands. In: Reddy, K. R., and Hodges, H. F. (eds.) Climate change and global crop productivity. CABI, Wallingford, Oxon, UK, pp. 293-314.

Prasad, P. V. V., Boote, K. J., Allen, L. H. Jr. and Thomas, M. G. (2003). Supra-optimal temperatures are detrimental to peanut (Arachis hypogaea L.) reproductive processes and yield at ambient and elevated carbon dioxide. Global Chage Biology 9, 1775-1787.

Purse, B.V., Mellor, P.S., Rogers, D.J., Samuel, A.R., Mertens, P.P.C. and Baylis, M. (2005). Climate change and the recent emergence of blue-tongue in Europe. Nature Reviews Microbiology 3, 171 - 181.
Ramanathan, V. and Carmichael, G. (2008). Global and regional climate changes due to black carbon. Nature Geoscience, 1 (14), $221-226$.

Reddy, K. R., Prasad, P. V. V. Kakani, V. G. (2005). Crop response to elevated carbon dioxide and temperature effects on cotton canopy photosynthesis, transpiration, and water use efficiency. Field Crops Research, 41, 13-23.

Reeves, W.C., Hardy, J.L., Reisen, W.K. and Milby. M.M. (1994). Potential effect of global warming on mosquito-borne arboviruses. Journal of medical entomology $31,323-332$

Renaudeau, D., Gourdine, J.L., Siva, B. and Noblet, J.(2005). Nutritional routes to attenuate eat stress - pigs. INRA Ani and Prod. Unit. Guadeloupe (FWI). Livestock and global climate change conference. May, $17-20^{\text {th }}$. Ppt.

Ricalde, S.H.R. and Lean, I.J. (2000). The effect of tropical ambient temperature on productive performance and frazing behaviour of soils kept in a outdoor system. Livestock research for rural development 12 (2). http://www.irrd.org/irrd12/2rica122.htm\#liv estockforruraldevelopment 2000

Rogers, D.J. and Randolph, S.E. (1993). Distribution of tsetse and ticks in Africa: past, Present and future. Parasitology Today 9, $266-271$.

Rowlinson, P. (2008). Adapting livestock production systems to climate change Temperate zones. Livestock and global change conference proceeding. May 2008, Tunisia.

Sankaran, M., Hanan, N.P., Scholes, R.J. ,Ratnam, J., Augustine, D.J., Cade, B.S., Gignoux, J., iggins, S.I., Le Roux, X., Ludwig, F., Ardo, J., Diouf, A., Ekaya, W., Feral, C.J., February, E.C., Forst P.G.., Hiernaux, P., Hrabar, H., Metzger, K.L., Prins, H.H.T., Ringrose, S., Sea, W., Tews, J., Worden, J. and Zambatis, N. (2005). Determinants of woody cover in African Savannas. Nature 438: $846-849$.

Schlesinger, M. and Zhao, Z.C. (1989).Seasonal climate changes induced by doubled $\mathrm{Co}_{2}$ as simulated by the OSU atmospheric. GCM mixed - layer ocean model, J. Clim. 2, 459 -495 .

Schneider, P. L., Beede, D.K. and Wilcox, C.J. (1986). Responses of lactating cows to dietary sodium source and quantity and 
potassium quantity during heat stress. J. Dairy Sci. 69: 99.

Schultz, T.A. (1988). California dairy corral manager mister installation: ASAE Paper No. 88 - 4056, ASAE, St. Joseph, M.I. USA.

Segnalini, M. and Nardone, A. (2010). Dynamics of the temperature - humidity index in the Mediterranean basin. Int. j. Biometeorology. DOI 10. 1007/5 00484 $010-0331-3$.

SEI (2008). Climate change and adaptation in African agriculture. Rockefeller foundation.

Sevi, A., Albenzio, M., Annicchiarico, G., Caroprese, M., Marino, R., and Taibi, L. (2002). Effects of ventilation regimen on the welfare and performance oflactating ewes in summer. J. Anim. Sci. 80: 2341 2361.

Shearer, J.K., Bray, D.R. and Buckhin, R.A. (2002). The management of heat stress in dairy cattle: What we have learned in Florida. University of Florida, America.

Sidahmed, A. (2008). Livestock and climate change: Coping and Risk management strategies for a sustainable future. Livestock and Global climate change conference proceeding, May, 2008, Tunisia.

Silanikove, N. (2000). Effects of heat stress on the welfare of extensively managed domestic ruminants. Livestock production science, $67,1-18$.

Smith, L.A. (2008). Climate modeling is still an abstraction of reality. The uncertainty in climate modeling: In: Roundtable discussion. Bulletin of Atomic Sciences. http://www.thebulletin.org/webedition/roundtables/the-uncertainty-climatemodeling.

Sprott, L. R., Selk, G. E. and Adams, D. C. (2001). Review: Factors affecting decions on when to calve beef females. Professional Animal Scientist, 17, 238-246.

Steinfeld, H., Gerber, P., Wassenaar, T., Castel, V., Rosales, M. and de Haan, C., (2006). Livestock's long shadow: Environmental issues and options. Rorue: Food and Agriculture Organization of the United Nations.

Stone, R.S., Anderson, G.P., Shettle, E.P., Andrews, E., Loukacine, K., Dutton, E.G., Schaaf, C. and Roman III, M.O. (2008). Rake in the Arctic: observed and modeled. Journal of Geophysical Research, 113, D14516, doi: 10. 1029/2007 JD009657.
Strickhin, W.R. (1986). Some factors affecting feeding patterns of beef cattle. In: Symposium: Intake by feedlot cattle. Oklahoma Agricultural Experiment station. Oklahoma State University, Stillwater,Ok, pp $314-320$.

Sutmoller, P., Barteling, S.S., Olascoaga, R.C. and Smption, K.J. (2003). Control and eradication of foot-and-mouth disease. Virus Research 91, $101-114$.

Svotwa, E., Makarau, A. and Hamudikuwanda, H. (2007). Heat tolerance of Mashona, Brahman and Simmental cattle breeds under warm humid summer conditions of natural region II area of ZImbabew. Election journal of environmental, Agricultural and food chemistry 6(4): 1934 - 1944.

Thompson, S. and Pollard, D.C. (1995). A global climate model (GENESIS) with a land surface transfer scheme (LSx) Part 1: Present climate simulation, J. Clim. 8, 732 761.

Thomson, A. M., Brown, R. A., Rosenberg, N. J., Izaurralde, R. C. and Benson, V.W. (2005). Climate change impacts for the conterminous U. S. A: An integrated assessment Part 3. dryland production of grain and forage crops. Climate Change, 69, 43-65.

Thornton, P., Hervevo, M., Freeman, A., Mwai, O., Rege, E., Jones, P. and McDermott, J. (2008). "Vulnerability, climate change and livestock - Research opportunities and challenges for poverty Alleviation". ILRI, Kenya.

Tietjen, R., Jeltsch, F., Zehe, E., Classen, N., Groengroeft, A., Schiffers, K. and Oldeland, J. (2010). Effects of climate change on the coupled dynamics of water and vegetation in drylands. Ecoyhdrology 3, 226 - 237.

Thomson, M.C., Connor, S.J., Ward, N. and Molyneux, D. (2004). Impact of climate variability on infections disease in West Africa. EcoHealth 1, 138 - 150.

Topping, J.C. Jr. (2007). Summit Aftermath: Study by NASA and University Scientists shows World Temperature Reaching a level Not seen in Thousands of years and Raises Grave Concern of Irreparable Harm. Available online at http://www.climate.org/2002/programs/was hington Summit temperature rise.shtml.

Turner, L.W., Chastain, J.P., Hemken, R.W., Gates, R.S., Crist, W.L. (1989). Reducing heat stress in dairy cows through sprinkler 
and fan cooling. ASAE Paper No 89 4025. ASAE, St. Joseph, M.I. USA.

Turnpenny, J.R. (2000a). Thermal balance of livestock. 1. A. Parsimonious model. Agric. Forest Meteorol., 101 pp. 15 - 27.

Turnpenny, J.R. (2000b). Thermal balance of livestock. 2. Application of a parsimonious model. Agric. Forest Meteorol., 101 pp. 29 -52 .

UNEP (2009). Climate change. UNEP year book pp $21-30$.

Vale, W.G. (2007). Effect of environment on buffalo reproduction. Hal. J. Anim.Sci. vol. 6 (Suppl. 2) $130-142$.

Valtorta, S.E. (2002). Animal production in a changing climate: Impacts and mitigation. (2002). Paper $15^{\text {th }}$ conf. on Biometeorology/Aerobiology and $16^{\text {th }}$ Int. congress of Biometeorology, 28 October 2002 Kansas City, M.O.

Vitali, A., Segnalini, M., Bertocchi, L., Bemabuci, U., Nardone, A. and Lacetera, N. (2009). Seasonal pattern of mortality and relationships between mortality and temperature humidity index in dairy cows. J. Dairy Sci. 92: 3781 - 3790.

Weaver, S.C. and Barrett, A.D.T. (2004). Transmission cycles, host range, evolution and emergence of arboviral disease. Nature Reviews Microbiology 2, 789- 801.
West, J.W. (2003). Effects of heat - stress on production in dairy cattle. J. Diary Sci. 86: 2131- 2144

White, P.C.L., Brown, J.A. and Harris, S. (1993). Badgers (meles-meles), cattle and bovine Tuberculosis (mycobacterium-Bovis) - a Hypothesis to Explain the influence of Habitat on the Risk of Disease Transmission in Southwest England. Proceedings of the Royal society of London series B-Biological sciences 253, 277 - 284.

Wosu, L.O., Okiri, J.E. and Enwezor, P.A.(1992). Optimal time for vaccination against peste des petits ruminants (PPR) disease in goats in the humid tropical zone in Southern Nigeria. In: Rey, B., Lebbie, S.H.B., Reynolds, L. (Eds.) Small ruminant research and development in Africa. Proceedings of the first Biennial conference of the African small Ruminant Research Network. ILRAD, Naivobi, Kenya 10 -14 December 1990.

Ziska, L. H., Reeves, J. B. and Blank, B. (2005). The impact of recent increases in atmospheric $\mathrm{CO}_{2}$ on biomass production and vegetative retention of Cheatgrass (Bromus tectorum): implications for fire disturbances. Global Change Biology, 11, 1325-1332. 